\title{
KOMUNIKASI TRANSENDENTAL DALAM RITUAL PARISUDHA VAYU DI PASRAMAN KAYU MANIS LATA MAHOSADHI DESA TEGALMENGKEB TABANAN
}

\author{
Putu Mia Kusuma Dewi a, 1 \\ I Wayan Wastawa \\ Ni Made Yuliani a \\ a Universitas Hindu Negeri I Gusti Bagus Sugriwa Denpasar \\ 1 Corresponding Author, email: miakusumadewi26@gmail.com (Dewi)
}

\section{ARTICLE INFO}

\section{Article history:}

Received: 16-07-2021

Revised: 13-08-2021

Accepted: 13-09-2021

Published: 30-09-2021

\section{Keywords:}

Transcendental Communication, Parisudha vayu Rituals, Kayu Manis Pasraman

\section{ABSTRACT}

\begin{abstract}
An interesting phenomenon at this time in Bali, Hinduism begin to make rituals of cleansing themselves not only as a spiritual activity but also as a life style. This study aims to one of them is the Parisudha vayu ritual, which means cleansing oneself by the wind power of Lord Vayu and is a method of activating oneself to connect with the energy of the universe. A sacred knowledge of Balinese ancestors stored in the natural silence of the village of Tegalmengkeb. This study focuses on the discussion of The process of transcendental communication in the implementation of the Parisudha vayu ritual at Pasraman Kayu Manis Lata mahosadhiforms of transcendental communication in the implementation of the Parisudha vayu ritual at Pasraman Kayu Manis Lata mahosadhi. The research objective is to develop transcendental communication in society. The results of this study indicate several things. First, ). the transcendental communication process goes through 3 stages in the parisudha vayu ritual, including: the preparation stage, namely establishing oneself and preparing the activation equipment, the implementation stage, namely the process of purifying the hands (karosodhana), the bhuwana chakra mudra movement and the activation of parisudha vayu and the final stage of giving three passwords. for the implementation of the next ritual. Second, the form of transcendental communication in the Parisudha vayu ritual is divided into two, namely verbal communication patterns (meaning in prayer in Parisudha vayu ritual) and nonverbal communication patterns (meaning in each movement in the Parisudha vayu ritual), respectively. -Each people practice. It is at this point that the private area of transcendental communication in the parisudha vayu ritual occurs (communication between humans and God. Third, the impact that is felt on Hindu religious life, Hindu community life and Hindu community life.
\end{abstract}

\section{PENDAHULUAN}

Fenomena yang menarik saat ini di Bali, umat Hindu mulai menjadikan aktivitas spiritual bukan hanya memenuhi kebutuhan rohaninya saja, bahkan juga sebagai life style. Banyak umat aktif mengikuti pasraman, tirtayatra ke tempat suci, juga ramairamai nangkil ke tempat penglukatan/pembersihan di hari-hari suci 
tertentu. Di Bali dikenal dengan 3 jenis penglukatan yaitu menggunakan media agni (Api), media gangga (air) dan maruta (angin). Seiring berjalannya waktu jenis penglukatan angin ini hilang, dan kini muncul kembali dan dikenal dengan ritual Parisudha vayu.

Parisudha vayu bersumber dari pengetahuan suci para leluhur Bali. Tersimpan dalam keheningan alam Tegalmengkeb yang kemudian disampaikan dengan perantara Ida Rsi Mahaprabu Prahlada Wirasa Pandya dalam meditasi di Pasraman Kayu Manis Lata mahosadhi, Desa Tegalmengkeb Kabupaten Tabanan. Parisudha vayu bermakna pembersihan/ penglukatan oleh kekuatan angin Dewa Vayu dan merupakan metode pengaktifan diri untuk terhubung dengan energi alam semesta. Di mana dalam Bhagawadgita bab IX sloka 31 disebutkan dalam "Pavanah Pavatam Asmi" yang berarti bahwa diantara yang paling membersihkan adalah Hyang Widhi dalam wujud angin.

Pengetahuan ini dapat dengan mudah diaktivasi dan bermanfaat langsung bagi keinginan manusia untuk mewujudkan cita-cita. Mewujudkan harmonisasi dengan alam semesta. Serta membuktikan keberadaan berkah dari dewa-dewa. Untuk mempelajari pengetahuan ini, maka seseorang cukup menghubungi instruktur/master yang sudah diajarkan langsung tata cara penyampaian pengetahuan ini oleh Ida Sri Mahaprabu Prahlada Pandya. Seorang praktisi yang pertamakali memperkenalkan Ritual Parisudha vayu di Bali pada tahun 2015, dengan mengadaptasi ritual Parisudha vayu melalui meditasi dan implementasi pustaka suci Bhagawadgita. dapat dengan mudah mendapatkan dukungan dari udara yang sangat segar untuk membersihkan/melukat diri serta lingkungannya. Inilah salah satu cara yang sangat relevan menjadi aktivitas spiritual saat ini, dari relaksasi mental dan fisik, menghilangkan stress dan solusi realisasi menciptakan kerukunan, kedamaian dan kesejahteraan umat.

Hal inilah yang begitu banyak menarik minat masyarakat tidak hanya umat Hindu yang ada di Desa Tegal Mengkeb, bahkan menyedot perhatian para akademisi, praktisi sampai birokrat yang ada di Bali juga luar Bali sekalipun untuk mempelajari, meneliti, dan melakukan praktik Ritual Parisudha vayu. Dalam ritual parisudha vayu ini ditemukan berbagai pola komunikasi, yaitu terdapat pola komunikasi verbal dan komunikasi non verbal. Namun yang utama terkandung dalam ritual ini adalah pola komunikasi transcendental. Pola transendental ini terealisasi dalam berbagai bentuk yang ada dalam ritual Parisudha vayu. Namun pola transcendental dalam komunikasi pada ritual ini masih kurang dipahami umat secara luas dan menyeluruh sehingga komunikasi transcendental dalam ritual Parisudha vayu ini layak diteliti.

Penelitian ini menguraikan tentang komunikasi transendental dalam ritual penyucian atau pembersihan melalui sebuah ritual Parisudha vayu/ penglukatan angin.adapun rumusan masalah dalam penelitian ini adalah : 1) Bagaimanakah proses pelaksanaan ritual Parisudha vayu di Pasraman Kayu Manis? 2) Bagaimana bentuk-bentuk komunikasi transendental dalam pelaksanaan ritual Parisudha vayu di Pasraman Kayu Manis? 3) Apa implikasi komunikasi transendental terhadap aspek kehidupan masyarakat setelah melaksanakan ritual Parisudha vayu di Pasraman Kayu Manis?

Pada kajian pustaka, akan dikemukakan teori, penelitian dan publikasi yang berhubungan dengan komunikasi transcendental dalam ritual penyucian atau pembersihan melalui sebuah ritual Parisudha vayu untuk dijadikan landasan dalam pembahasan penelitian ini. Menurut I Wayan 
Rusdika, dkk (2018) dalam jurnal ilmiahnya, prosesi mapajejiwan yang dilakukan oleh dua orang sulinggih dengan membaca teks dialog suci adalah bentuk nyata dari penerapan komunikasi transendental. Penelitian dengan topik yang senada juga dilakukan oleh Hardin (2016) dalam jurnal penelitiannya yang berjudul, komunikasi transendental dalam ritual kapontasu pada masyarakat etnik Muna. Junrnal penelitian ini menguraikan tentang proses pelaksanaan dan makna ritual kapontasu dalam kaitannya dengan komunikasi transendental dan menganalisis simbol-simbol yang terdapat di dalamnya; berupa bhatata (mantra), sesaji, bahan-bahan ritual kapontasu.

Nina Syam Winangsih (2015) dalam bukunya yang berjudul, Komunikasi Transendental Perspektif Sains Terpadu. Buku ini menguraikan tentang salah satu wujud berpikir tentang bagaimana menemukan hukum-hukum Alam, dan keberadaan manusia dengan Tuhannya atau antara manusia dengan kekuatan yang berada diluar kemampuan pikir manusia yang keberadaannya dilandasi oleh rasa cinta. Maka, diartikan bahwa Komunikasi transendental adalah komunikasi yang berlangsung dalam diri dengan sesuatu di luar diri yang keberadaannya disadari oleh individu. Dari defenisi ini, dapat dipahami bahwa komunikasi transcendental merupakan komunikasi yang terjadi di dalam diri dengan diluar diri, yang bersifat intrapersonal. Namun halnya dalam buku ini lebih menekankan pada komunikasi spiritual antara umat dengan Tuhan yang diyakini dalam keyakinan agama Islam.

Walaupun buku ini mampu menjelaskan secara eksplisit dan menyeluruh tentang komunikasi transendental, namun peneliti masih perlu mengkaji kembali reaksi yang berbeda apabila paradigma berubah menjadi perspektif Hindu. Dengan demikian buku karya Prof. Nina ini akan dijadikan data sekunder untuk memahami konsep penelitian lebih lanjut namun khusus dalam lingkup penelitian agama Hindu.

Selanjutnya jurnal penelitian Tania (2018) dari Fakultas Ilmu Komunikasi Universitas Tarumanagara dengan judul, Komunikasi Transendental Sembahyang Buddha Mahayana (Studi Semiotika Sembahyang Di Vihara Padumuttara Tangerang). Jurnal ini menguraikan tentang Sembahyang yang dilakukan oleh umat Buddha Mahayana di Vihara Padumuttara merupakan bentuk kegiatan komunikasi antara manusia dengan Tuhan sehingga membentuk makna yang dipahami bersama. Jadi fokus utama jurnal ini adalah membahas makna semiotika pada komunikasi transendental sembahyang Buddha Mahayana di Vihara Padumuttara Tangerang. Namun halnya dalam penelitian ini hanya menekankan pada komunikasi simbolis pada umat Buddha. Di sisi lain ulasan dalam jurnal ini sangat mendalam dan terintegrasi baik dengan dilengkapi alur atau tahapan proses persembahyangan umat Buddha sehingga bisa menjadi acuan peneliti dalam menguraikan rumusan masalah penelitian. Ditambah peneliti perlu wawancara mendalam dan referensi menunjang penelitian. Dengan demikian hasil penelitian Tania akan dijadikan data penunjang peneliti.

A.W Widjaja (2018) dengan jurnal penelitian yang berjudul, Meditasi Transendental Sebagai Bentuk Komunikasi Sosial di Padepokan Jaya Giri Kusuma Cimahi. Jurnal penelitian ini menguraikan tentang Perubahan sosial dalam masyarakat dunia, sedikit banyak akan saling berpengaruh terhadap perubahan sosial dalam berbagai kelompok masyarakat di negara-negara lain. Selo Soemardjan menyatakan bahwa Perubahan sosial adalah perubahan-perubahan pada lembaga-lembaga masyarakat yang mempengaruhi sistem sosialnya, termasuk didalamnya nilai-nilai, sikap-sikap, dan polapola perilaku. 


\section{METODE PENELITIAN}

Penelitian tesis ini adalah jenis penelitian komunikasi dengan metode penelitian kualitatif yang akan dilakukan dengan pendekatan paradigma komunikasi fenomenologi. Penelitian ini mengambil lokus secara fisik, Pasraman kayu manis Lata mahosadhi Desa Tegalmengkeb Kecamatan Selemadeg Timur Kabupaten Tabanan. Jenis data dalam penelitian ini adalah data berupa informasi hasil wawancana dan data hasil kutipan percakapan informan di Pasraman Kayu Manis Lata mahosadhi.

Sumber data dalam penelitian ini terbagi menjadi dua tipe yaitu : Sumber data primer dalam penelitian ini adalah informan kunci, yakni mereka yang mengetahui dan merasakan banyak tentang komunikasi transendental dalam ritual Parisudha vayu di Pasraman kayu manis. Sumber data sekunder, ialah berupa buku-buku pustaka, dan berbagai dokumen yang ada kaitannya dengan penelitian ini, seperti dokumen, kitab suci, dan bacaan yang mempunyai korelasi dengan ilmu komunikasi transendental dan ritual Parisudha vayu.

Dalam penelitian kualitatif, yang menjadi instrumen utama penelitian ini adalah peneliti sendiri. Dalam membantu melaksanakan penelitian, peneliti sebagai instrumen kunci menggunakan beberapa instrumen bantu untuk mempermudah dalam mengumpulkan data. Instrumen tambahan untuk memudahkan penelitian terdiri dari pedoman wawancana, alat-alat merekam data seperti handphone, buku catatan, alat-alat tulis, pedoman wawancara, laptop, kendaraan untuk mobilisasi ke lapangan serta kamera untuk mendokumentasikan segala aktivitas terkait penelitian.
HASIL DAN PEMBAHASAN

Proses Pelaksanaan Ritual Parisudha Vayu di Pasraman Kayu Manis.

Proses yang dilewati selama ritual parisudha vayu berlangsung merupakan bagian dari komunikasi yang disebut proses komunikasi transendental. Dalam khazanah ilmu komunikasi, komunikasi transendental merupakan salah satu bentuk komunikasi di samping komunikasi antarpersona, komunikasi kelompok, komunikasi organisasi,komunikasi antar budaya, komunikasi verbal, komunikasi non-verbal dan komunikasi massa. Namun komunikasi transendental tidak pernah dibahas luas. Cukup dikatakan bahwa komunikasi transendental adalah komunikasi antara manusia dan Tuhan( Deddy Mulyana:2007).

Ajaran agama Hindu mengatakan dalam proses mencapai hubungan yang baik dengan Tuhan, salah satunya melalui konsep Panca Yadnya. Suatu yadnya baik itu Manusa Yadnya, Pitra Yadnya, Rsi Yadnya, Dewa Yadnya maupun Bhuta Yadnya mempunyai tahapan pelaksanaannya masing-masing. Ritual Parisudha vayu bagian dari kelima elemen dari Panca Yadnya yang mempunyai tahapan sama yang diawali tahap persiapan.

Tahap persiapan ini merupakan tahap dimana para pelaksana yadnya baik itu pihak yang menyelenggarakan upacara maupun pihak lainnya untuk melaksanakan persiapan. Persiapan ini dapat berupa persiapan sarana upakara, tempat maupun lainnya yang diperlukan pada saat melaksanakan ritual tersebut. Ritual ini yang dilaksanakan oleh masyarakat umum yang ingin aktivasi di Pasraman Kayu Manis, Desa Tegalmengkeb, Selemadeg Timur, Tabanan, biasanya dipimpin oleh Maha Master atau Master. Untuk lebih jelasnya peneliti akan menuangkan proses pelaksanaan ritual parisudha vayu dengan tiga tahapan, diantaranya : 1) Tahapan Persiapan, 2) 
Proses Pelaksanaan dan 3) Tahap akhir. Adapun deskripsinya dituangkan sebagai berikut.

\section{Tahap Persiapan}

Tahap persiapan adalah tahap pertama pada suatu kegiatan keagamaan maupun lainnya. Tahap persiapan merupakan tahap dimana para pelaksana ritual dapat mempersiapkan berbagai sarana dan prasarana suatu ritual yang akan dilaksanakan. Pada tahap ini, peserta yang ingin aktivasi dianjurkan untuk menyiapkan diri dan juga menyiapkan sarana upakara pejati dan segehan putih kuning. Yang artinya peserta siap mengikuti ritual Parisudha vayu secara siap fisik dan mental serta siap menerima arahan dari para master selama ritual berlangsung. Sebelum melakukan aktivasi Parisudha vayu, peserta diberikan pengetahuan tentang Parisudha vayu.

\section{Tahap Pelaksanaan}

Tahap pelaksanaan adalah tahap kedua pada suatu kegiatan keagamaan maupun lainnya. Tahap pelaksanaan merupakan tahap dimana para pelaksana ritual sudah memulai suatu prosesi suatu ritual. Pada tahap ini, peserta diminta untuk memohon izin kepada Hyang Leluhur untuk melaksanakan Parisudha vayu dan memohon agar selama prosesi ritual berlangsung dengan lancar. Master Parisudha vayu memimpin doa dari peserta. Setelah memohon izin dari Hyang Leluhur, peserta diminta untuk merasakan energi dari alam sekitar. Pada tahap ini Master meminta peserta untuk mengikuti langkah-langkah aktivasi Parisudha vayu, diantaranya:

Karosodhana, Sikap berupa gerakan penyucian kedua tangan oleh master dan peserta ritual parisudha vayu sebagai upaya mendapatkan anugerah sentuhan di kedua telapak tangan oleh kekuatan Tuhan. Peserta diminta untuk memejamkan kedua mata sambil mengangkat kedua telapak tangan dan merasakan energi dari Dewa Vayu.Sikap ini berfungsi untuk mendoakan kedua tangan kita agar layak melaksanakan ritual dan persembahyangan.

Cakra bhuwana, merasakan keberadaan gelembung energi alam yang sangat bagus untuk dipakai berdoa. Peserta diminta untuk memejamkan kedua mata dan kedua telapak tangan saling berhadapan. Pada sikap ini, Master memberikan sugesti untuk merasakan energi diri peserta dan Master akan memberikan arahan untuk pertemukan telapak tangan dan menjauhkan telapak tangan untuk merasakan gelembung energi. Dua sebab muasal inilah yang pertama-tama wajib disadari oleh orang yang hendak melaksanakan ritual parisudha vayu agar dengan cakra bhuwana dapat mencapai kesempurnaan hidup melalui tuntunan master/guru. Kesempurnaan hidup itu tiada lain adalah menyadari bahwa nafas masuk dan nafas ke luar itu adalah wujud nyata kehadiran-Nya sebagai kehidupan dan sekaligus sebagai kematian. Nafas masuk adalah kehidupan. Dalam aksara Bali dilambangkan dengan ö Ang atau Ang-kara.

Parisudha vayu, merasakan secara langsung kekuatan khusus anugerah Dewa Vayu. Pada sikap ini peserta diminta untuk mengangkat kedua tangan keatas dengan telapak tangan dibuka. Dengan mengucapkan mantra "Jay Narayana Jay Sri Hanuman Jay Mahaprabhu". ritual Parisudha Vayu di Pasraman Kayu Manis adalah suatu ritual yang dilakukan para masyarakat Agama Hindu untuk pembersihan atau penglukatan dengan media angin dan merupakan metode pengaktifan diri untuk terhubung dengan energi alam semesta. Ritual Parisudha vayu di Pasraman Kayu Manis adalah suatu ritual yang dilakukan para masyarakat Agama Hindu untuk pembersihan atau penglukatan dengan media angin dan merupakan metode pengaktifan diri untuk terhubung dengan energi alam semesta. 


\section{Tahap Akhir}

Tahap akhir adalah proses terakhir dari suatu kegiatan keagamaan maupun lainnya. Proses akhir merupakan proses di mana para pelaksana ritual akan mengakhiri ritual keagamaan. Pada tahap ini, peserta yang sudah melaksanakan tiga sikap dalam melaksanakan aktivasi, Master akan memberikan arahan bagi peserta untuk duduk hening seperti sikap meditasi. Master akan memberikan sugesti untuk merasakan hembusan angin di seluruh tubuh. Pada proses akhir ini peserta akan merasakan merasakan hembusan angin di sekeliling tubuh. Dan ini menunjukkan bahwa peserta telah melaksanakan aktivasi Parisudha vayu dan telah direstui oleh Dewa Vayu. Kemudian Master meminta kepada peserta dengan mencakupkan kedua tangan dan mengucapkan terimakasih kepada Dewa Bayu, Dewa Narayana, Hyang Leluhur atas ritual Parisudha vayu berjalan dengan lancar.

Setelah melaksanakan ritual tersebut, peserta diminta untuk melaksanakannya secara pribadi di rumah dua kali sehari setiap pagi sebelum mulai aktivitas dan sore hari setelah aktivitas. Melalui ritual Parisudha vayu ini seseorang mendapatkan pendidikan budi pekerti agar nantinya mereka membiasakan diri untuk menyucikan diri. Dengan selalu melaksanakan dan mampu mempertahankan kesucian diri dari berbagai aspek ajaran agama diharapkan mereka mampu mencapai tujuan hidup Agama Hindu yaitu "Moksartham Jagadhita Ya Ca Iti Dharma".

\section{Bentuk-bentuk Komunikasi Transendental dalam Pelaksanaan Ritual Parisudha Vayu di Pasraman Kayu Manis}

Bentuk-bentuk komunikasi transendental tertuang dalam berbagai bentuk aktivitas spiritual umat beragama dalam berkomunikasi dengan Tuhan. Berbagai pola dan bentuk ada dalam setiap proses dari ritual keagamaan yang sedang berlangsung seperti bentuk komunikasi intrapersonal. Bentuk komunikasi intrapersonal yang dilakukan sehari-hari dalam upaya memahami diri pribadi diantaranya adalah; berdo'a, bersyukur, instrospeksi diri yang diluapkan dengan bentuk aktivitas keagamaan atau ritual. Dalam ilmu komunikasi, bentukbentuk yang sering diterapkan sehari-hari dibagi menjadi dua yaitu verbal dan nonverbal.

Komunikasi verbal meliputi Simbol atau pesan yang menggunakan satu kata atau lebih, dari semua interaksi yang disadari termasuk dalam kategori disengaja yang dilakukan dengan sadar ke orang lain baik itu menggunakan lisan. Bahasa juga digunakan dalam kode verbal dan dapat didifinisikan sebagai perangkat simbol, dengan aturan dan yang mengkombinasikan simbol-simbol tersebut, yang digunakan dalam memahami suatu komunitas-komunitas. (Mulyana, 2005). Komunikasi non verbal adalah semua komunikasi yang tidak menggunakan kata-kata. Komunikasi ini mencangkup semua rangsangan kecuali ransangan verbal dalam suatu sistem komunikasi, yang bagi pengirim atau penerima, dan kita mengirim pesan non verbal tanpa menyadari bahwa pesan-pesan tersebut bermakna bagi orang lain. (Mulyana, 2005:343)

Rangsangan dalam bentuk lambanglambang, tanda-tanda atau kejadian-kejadian juga bagian dari komunikasi antara peserta dengan master ritual parisudha vayu. Persepsilah yang menentukan peserta memilih pesan tertentu dan mengabaikan yang lain, memberi makna tertentu pada pesan tersebut dan tidak memberi makna lain. Karena tidak ada umat yang mempunyai pengalaman yang persis sama, maka tidak ada dua umat yang mempunyai persepsi yang sama terhadap suatu rangsangan. Agar dapat mencapai tujuan relatif yang diinginkan, Peserta harus mempelajari bentuk bentuk komunikasi serta simbol-simbol yang ada didalamnya. Untuk lebih jelasnya dalam 
pembahasan ini peneliti membagi dua jenis komunikasi sebagai penjabaran bentuk komunikasi transcendental dalam ritual Parisudha vayu, diantaranya : Jenis Komunikasi verbal dan jenis komunikasi non verbal.

\section{Komunikasi Verbal dalam Ritual Parisudha Vayu}

Komunikasi verbal dalam komunikasi transenden adalah komunikasi dengan menggunakan kata-kata sebagai simbol dalam setiap proses dalam tahapan ritual Parisudha vayu. Simbol verbal komunikasi transenden menjadi ciri khas komunikasi yang terjadi antara Master dan peserta aktivasi ritual Parisudha vayu. Peserta yang sedang mendengar wejangan Maha Master Parisudha vayu saat tahapan persiapan sebagai bekal peserta memahami sejarah tentang pengetahuan suci ini juga bagian dari pemantapan mental dan fisik peserta diwujudkan dengan penekanan bentuk komunikasi verbal pada peserta ritual.

Hal tersebut digunakan sebagai media untuk mengkomunikasikan pesan-pesan yang ingin disampaikan oleh komunikator kepada komunikan dengan bahasa sebagai media komunikasi. Hal ini dipertegas oleh Dedy Mulyana (2010:73) yang menyatakan bahwa komunikasi verbal adalah semua jenis simbol yang menggunakan satu kata atau lebih. Hampir semua rangsangan wicara termasuk ke dalam kategori pesan verbal.

Bahasa dapat didefinisikan sebagai seperangkat simbol dengan aturan untuk mengkombinasikan simbol-simbol tersebut, yang digunakan, dipahami suatu komunitas. Bahasa verbal adalah sarana utama untuk mengatakan pikiran, perasaan dan maksud kita. Komunikasi verbal menggunakan kata-kata yang mempresentasikan berbagai aspek realitas individual. Saat aktivitas ritual pembersihan parisudha vayu ini berlangsung, bentuk komunikasi verbal adalah mantra-mantra suci serta password yang diucapkan oleh maha master dan peserta ritual parisudha vayu.

Pada saat Maha Master memulai aktivasi penglukatan angin, para peserta duduk mengambil posisi Padmasana untuk laki-laki dan bajrasana untuk perempuan. Selanjutnya siap mendengarkan Ida Maha Prabhu Patni memberikan wejangan dharma hakikat kehidupan dan sekilas mendalam tentang ritual pembersihan atau penglukatan angin. Ini merupakan proses awal dalam ritual parisudha vayu, Pada tahapan digolongkan dalam bentuk komunikasi verbal dengan penekanan kuat pada kata-kata sebagai sitimulus kuat berbentuk pengetahuan sebagai bekal peserta melewati proses pelaksanaan selanjutnya.

Dalam komunikasi verbal ini terjadi proses komunikasi secara langsung. Komunikator yaitu Maha Master dan master Parisudha vayu serta umat atau peserta yang siap melakukan pembersihan atau penglukatan angin. Sementara komunikannya adalah Hyang Widhi dalam kualitas konsentrasi sebagai Dewa Bayu. Sedangkan pesan yang disampaikan adalah berupa rasa tulus bhakti untuk memuja kebesaran Ida Sang Hyang Widhi Wasa dalam manifestasinya sebagai Dewa Wisnu dan memohon anugerah pembersihan atau penglukatan oleh angin. Adapun media yang digunakan adalah bahasa berupa doa dan mantra suci berupa password.

Kegiatan ritual memungkinkan para pesertanya berbagi komitmen, emosional dan menjadi perekat bagi kepaduan mereka, juga sebagai pengabdian kepada kelompok. Ritual menciptakan perasaan tertib (a sense of order) dalam dunia yang tanpanya kacau balau. Ritual memberikan rasa nyaman akan keteramalan (a sense of predictability). Untuk memahaminya lebih luas dan mendalam, jenis komunikasi verbal dalam ritual parisudha vayu diantaranya melalui : 1) Sumber Pustaka Suci Weda pada Ritual Parisudha vayu, 2) Proses Pengenalan dan 
Pemantapan jiwa oleh Master Parisudha vayu dan 3) Doa dalam bentuk password dalam Ritual Parisudha vayu.

\section{Komunikasi Non Verbal dalam Ritual Parisudha Vayu}

Menurut Deddy Mulyana (2007 : 353), "orang Indonesia terbiasa lebih mementingkan simbol (kulit) dari pada apa yang disimbolkannya (subtansi)". Berarti bisa jadi kita merasa kagum dan berfikiran positif ketika kita melihat orang yang bertato dengan melihat warna kulit pengguna tato tersebut putih dan bersih. Begitu juga sebaliknya, kita akan berpikir negatif ketika pengguna tato itu berpenampilan acak-acakan atau kusam. Sebagaimana katakata, kebanyakan isyarat nonverbal juga tidak universal, melainkan terikat oleh budaya, jadi di pelajari untuk memahami komunikasi nonverbal tersebut bukan merupakan bawaan. Karena kebanyakan prilaku nonverbal bersifat spontan, ambigu, sering berlangsung cepat, dan di luar kesadaran dan kendali seseorang.

Komunikasi nonverbal sangatlah berbeda dengan komunikasi verbal, karena komunikasi verbal selalu berkaitan dengan kata-kata dan bahasa sedangkan komunikasi nonverbal berkaitan dengan gerakan tubuh, simbol, lambang atau logo dan masih banyak lainya. Maka dari itu peneliti menangkap dua pola yang berbeda dalam praktek ritual parisudha vayu. Hal yang paling mendasar dalam jalannya ritual ini adalah bentuk komunikasi non verbal melalui gerak ritmik yang mengalir seperti melakukan pola pernafasan atau pranayama dan sikap mudra dalam aktivasi cakra bhuwana melalui sikap yoga yang meditatif yang menenangkan.

Dalam sudut Pandangan Ilmu Pengetahuan \& Fusi Atomic Fusion dalam Science, tubuh manusia merupakan reaktor yang sangat luar biasa. Tubuh manusia juga dapat dikatakan sebagai katalisator. Padahal khusus dalam pelaksanaan ritual Parisudha vayu, ada satu teori dalam atom yang secara nyata dirasakan, yaitu ketika atom itu mulai terpecah terpisah dari atom-atom lainnya maka yang muncul pada reaksi berupa hembusan udara. Mungkin kita mempelajari fisika quantum tentang atom pastinya akan menemukan itu. Jadi ketika kita memulai ritual dengan sikap duduk Parisudha vayu, diawali dengan doa memohon agar energi sekeliling kita menjadi sejuk dan segar atau hangat dan segar.

Makna ritual Parisudha vayu sebagai wujud pembersihan bagi umat Hindu, selain mengandung unsur komunikasi transendental verbal, juga sarat dengan pesan-pesan nonverbal berupa gerakan gerakan simbol yang relevan dengan keyakinan umat Hindu. Gerakan-gerakan yang memiliki makna ritual Parisudha vayu sendiri (sebagai bentuk komunikasi transendental nonverbal), bukan suatu gerakan yang hampa akan tujuan dan makna filosofis. Berikut akan dijelaskan beberapa makna di balik simbol-simbol nonverbal dalam ritual Parisudha vayu. Pengetahuan ini dibagi menjadi 5 terminasi yaitu : 1) Sarana Banten Pejati saat aktivasi Parisudha vayu, 2) Arti dan Makna dalam Simbol Parisudha vayu, 3)Pola Gerakan Pembersihan Tangan (Karosodhana ), 4) pola gerakan penyucian mudra (Cakra Bhuwana) dan 5) pola komunikasi transcendental dalam doa Peserta Ritual Parisudha vayu.

\section{c. Implikasi Komunikasi Transendental terhadap Aspek Kehidupan Masyarakat setelah Melaksanakan Ritual Parisudha Vayu di Pasraman Kayu Manis.}

Implikasi merupakan suatu konsekuensi atau akibat langsung dari hasil penemuan suatu penelitian ilmiah. Pengertian lainnya dari implikasi menurut para ahli adalah suatu kesimpulan atau hasil akhir temuan atas suatu penelitian. Implikasi atau efek suatu permasalahan dalam penelitian yang bereaksi terhadap objek adalah implikasi yang dapat 
dirasakan subjek penelitian. Sehingga dalam penelitian ini akan dituangkan implikasi komunikasi transendental terhadap aspek kehidupan masyarakat setelah melaksanakan ritual Parisudha vayu.

Terkait dengan implikasi komunikasi transcendental terhadap aspek kehidupan masyarakat setelah melaksanakan ritual Parisudha vayu, akan dituangkan tiga elemen yang terkait dengan efek yang dirasakan langsung oleh umat. Diantaranya : 1) Implikasi Komunikasi Transendental pada kehidupan Religius usai melaksanakan Ritual Parisudha vayu, 2) Implikasi Komunikasi Transendental pada kehidupan Keluarga usai melaksanakan Ritual Parisudha vayu, dan 3) Implikasi Komunikasi Transendental pada kehidupan Sosial usai melaksanakan Ritual Parisudha vayu.

\section{Implikasi Komunikasi Transendental pada Kehidupan Religius}

Kehidupan sosial religius Umat Hindu merupakan suatu kebiasaan yang telah mendarah daging dan turun temurun dilakukan secara mendasar dalam adat dan budaya khususnya di Bali. Umat Hindu yang datang ke pasraman kayu manis "Lata mahosadhi", merasakan dan mengalami langsung apa saja implikasi yang dirasakan dalam jiwa rohani dan jasmani mereka. Bagaimana hubungan manusia kepada Sang Pencipta yang tidak dapat diungkapkan dan diukur melalui sebuah tolak ukur dari manusia. Keyakinan yang dianut Umat Hindu merupakan hasil dari tradisi yang telah melekat sejak dini.

Ritual parisudha vayu atau penglukatan angin dalam tradisi masyarakat Bali Hindu memiliki implikasi spiritual yang begitu variatif. Awalnya tradisi penglukatan hanya sebatas ritual pembersihan dari sumber mata air atau air suci yang telah diberikan doa. Saat ini dengan munculnya pengetahuan suci Parisudha vayu membuat masyarakat atau umat Hindu memiliki semacam alternatif penyegaran spiritualitas baru yang mulai menyebar secara terarah. Ritual parisudha vayu tidak mengubah dan meninggalkan kebiasaan atau tradisi ritual penglukatan yang pada umumnya dilakukan umat Hindu, melainkan kembali mengingatkan umat, bahwa ada tiga jenis penglukatan berdasarkan tradisi agama Hindu di Bali, penglukatan gangga, penglukatan agni dan penglukatan maruta. Ritual parisudha vayu adalah pengetahuan universal yang dapat menggerakkan energi angin untuk memulihkan/memurnikan diri dan lingkungan diseumatr umat.

Implikasi filosofis yang hadir dalam sebuah ritual ini tidak hanya dalam perspektif religius sebagai wujud ungkapan doa dan pertolongan, melainkan memiliki perkembangan makna baik secara psikologis maupun sosiologis (Hasanah, 2013:3). Implikasi religius dari ritual parisudha vayu, menyangkut persoalan internalisasi nilainilai ajaran agama dalam kehidupan. Parisudha vayu mengandung nilai pemurnian, pencerahan serta budhi pekerti luhur.Aspek nilai inilah yang akan dimanfaatkan oleh manusia dalam mengemban swadharmanya di masyarakat.

Implikasi psikologis dari ritual parisudha vayu pada saat ini, tidak hanya sebatas pada reaksi dari bentuk komunikasi transcendental, melainkan mengarah pada pembentukan dinamika psikologis yang lebih komplek. Dinamika psikologis ini diwujudkan dalam bentuk keakraban, kedekatan, respon emosional positif, rasa saling mengasihi, berbagi. Dinamika psikologis parisudha vayu adalah perubahan sikap dan perilaku positif, bersifat integralkomprehensif. Artinya, parisudha vayu membentuk seseorang memancarkan aura positif dalam keheningan dan kedamaian sehingga bersikap, memandang agamanya secara universal, dan mengembangkan sikap toleran. Parisudha vayu melahirkan sikap dan perilaku motivasional dan inspiratif. Motivasi 
untuk hidup dalam kedamaian, ketentraman, keunggulan, dan kesejahteraan. Selalu bersemangat dan memiliki inspirasi dalam menjunjung tinggi nilai-nilai tradisi parisudha vayu.

Pelaksanaan parisudha vayu sering dianggap sebagai ritual pembersihan diri yang penting untuk dilakukan setiap harinya. Masyarakat yang disibukkan dengan aktivitas kerja yang banyak menyedot tenaga, pikiran dan waktu sehingga mengabaikan religiusitaspun juga akan mulai beranjak melaksanakan ritual Parisudha vayu melalui informasi teman temannya yang telah melakukan aktivasi. Melalui parisudha vayu, seakan tersentak kesadaran hati nuraninya untuk kembali bersentuhan dan bercengkrama dengan nilainilai agama. Implikasi sosiologis lain dari parisudha vayu di Pasraman Kayu manis dijadikan sebagai salah satu sarana spiritualitas budaya, yang menghadirkan berbagai macam pola mudra dan yoga dalam proses jalannya ritual tersebut.

Dalam sebuah kegiatan keagamaan yang membutuhkan waktu yang cukup lama tentu akan menimbulkan implikasi terhadap lingkungan masyarakat. Semua itu dikarenakan komunikasi yang terjadi dalam pelaksanaan upacara tersebut. Umat Hindu dalam serangkaian melakukan kegiatan penglukatan atau pembersihan dengan angin serta datang mengaktivasi ritual tersebut ke Pasraman kayu manis "Lata mahosadhi", pasti memiliki alasanalasan tertentu.

Terkait dengan permasalahan yang tidak bisa terselesaikan. Setiap orang punya masalah, bentuk permasalahan itu berbeda-beda. setiap masalah bermuara dari karma manusia itu sendiri. Maka dari itu manusia harus selalu mawas diri mampu mengendalikan diri, dengan mendekatkan diri pada Tuhannya. Sehingga hasil yang diperoleh dengan budi pekerti yang baik berimplikasi positif bagi umat Hindu dalam kehidupannya, baik dalam hal sosial, religius dan yang paling pribadi sekalipun.

\section{Implikasi Komunikasi Transendental pada Kehidupan Keluarga}

Keluarga adalah unit terkecil dari masyarakat yang terdiri atas kepala keluarga dan beberapa orang yang terkumpul dan tinggal di suatu tempat di bawah suatu atap dalam keadaan saling ketergantungan. Menurut Salvicion dan Celis (1998) di dalam keluarga terdapat dua atau lebih dari dua pribadi yang tergabung karena hubungan darah, hubungan perkawinan atau pengangkatan, di hidupnya dalam satu rumah tangga, berinteraksi satu sama lain dan di dalam perannya masing-masing dan menciptakan serta mempertahankan suatu kebudayaan.

Implikasi Komunikasi transcendental pada kehidupan keluarga umat usai melaksanakan ritual parisudha vayu tentu mempengaruhi unit terkececil dalam tatanan masyarakat ini. Keluarga memiliki kehidupan pribadi yang sangat tabu, dan jarang menjadi topik utama untuk dibicarakan ke khalayak ramai, karena bersifat rahasia dan tidak pantas untuk dipublikasikan ke banyak orang. Namun terkadang apabila kehidupan pribadi tersebut sudah menimbulkan masalah yang tidak bisa dipecahkan secara pribadi bahkan antara orang yang bersangkutan, bisa menjadi malapetaka penghancur sebuah keluarga bahkan hubungan tertentu. Sehingga kehidupan pribadi perlu dijaga dan diwujudkan menjadi sesuatu hal yang positif sesuai yang diinginkan umat tersebut. Kondisi masyarakat yang semakin individualis dewasa ini, konsep ajaran agama yang harus diimplementasikan sesungguhnya sangat berperan dalam menanamkan nilai-nilai moral, sikap sosial, dan nilai-nilai spiritual kepada sang anak dengan menyentuh kehidupan faktual dan praksis. 
Terkait hal tersebut, maka implikasi komunikasi transcendental usai melaksanakan ritual parisudha vayu secara rutin membuat hal semacam itu tidaklah sulit. Sehingga lingkungan keluarga dapat menciptakan suasana yang kondusif dalam proses pembelajaran guna menyadarkan para anak atau anggota keluarga lainnya agar mampu menghayati roh dari sebuah kerukunan dan kesejahteraan di dalam keluarga, yakni iman, harapan, dan kasih. Berikut ini akan diuraikan Implikasi komunikasi transendental pada kesehatan anggota Keluarga.

\section{Implikasi Komunikasi Transendental pada Kehidupan Sosial}

Kehidupan Sosial Umat Hindu merupakan sebuah pola interaksi yang dinamis dan fleksibel. Manusia tidak dapat hidup sendiri karena manusia merupakan makhluk sosial sehingga perlu adanya kesadaran dalam diri untuk terus belajar dan berusaha menjalani hidup ini dengan kehidupan sosial di masyarakat. Dalam keadaan ini, umat yang datang ke Pasraman Kayu Manis juga melakukan aktivasi parisudha vayu dengan tujuan untuk meningkatkan dirinya dalam bidang sosial diantaranya meningkatkan kesejahteraan, perekonomian, kemakmuran, hubungan relasi yang baik di lingkungan kerja dan lainnya yang berorientasi pada tindak prilaku manusia yang sosial. Dalam pelaksanaan kegiatan sosial kemasyarakatan di Pasraman Kayu Manis juga memiliki agenda tahunan dengan menggelar serentetan acara seperti yang pertama dharma wacana, kemudian dharma tula, dan dilanjutkan dengan nunas prasadam atau makan bersama umat yang datang ke pasraman Kayu manis.
Selanjutnya implikasi sosial komunikasi transendental dalam ritual pariudha vayu diantaranya dengan pola komunikasi transcendental yang digunakaan saat ritual tentu telah membantu masyarakat yang telah melaksanakannya menjadi paham dan merasa diri menjadi sehat jasmani dan rohani dalam beraktifitas di lingkungan masyarakat. Lingkungan sosial yang ada pada masyarakat, tentu menjadi pilihan yang mudah bagi umat yang telah melaksanakan ritual parisudha vayu. Berdasarkan hasil wawancara dan kegiatan yang telah dilaksanakan di pasraman kayu manis menjadi bukti bahwa komunikasi transendendal pada ritual pembersihan parisudha vayu, dapat menyatupadukan dinamika perbedaan yang ada di masyarakat dan membangun tatanan sosial yang lebih kuat.

Tidak hanya membangun hubungan baik antar anggota pasraman saja, dengan ritual parisudha vayu juga memperkuat hubungan masyarakat di desa tegal mengkeb dengan masyarakat lainnya yang datang hanya untuk melaksanakan ritual pembersihan dengan angin atau dewa bayu ini. Sehingga sebagaimana yang tersurat dalam visi misi pasraman dalam ritual ini membuat hubungan masyarakat Bali umumnya secara terus menerus berkesinambungan. Memahami bahwa semuanya adalah ciptaan Tuhan agar tercipta dan terwujud jargon Pasraman, 'rukun, damai dan sejahtera'. Secara umum komunikasi transcendental dalam ritual parisudha vayu memberikan implikasi kepada hubungan antara manusia dengan Tuhan, antar dengan sesama manusia dan hubungan antara manusia dengan alam 


\section{Gambar 1}

Sikap Cakra Bhuwana saat Ritual Parisudha Vayu oleh Ida Mahaprabhu Patni

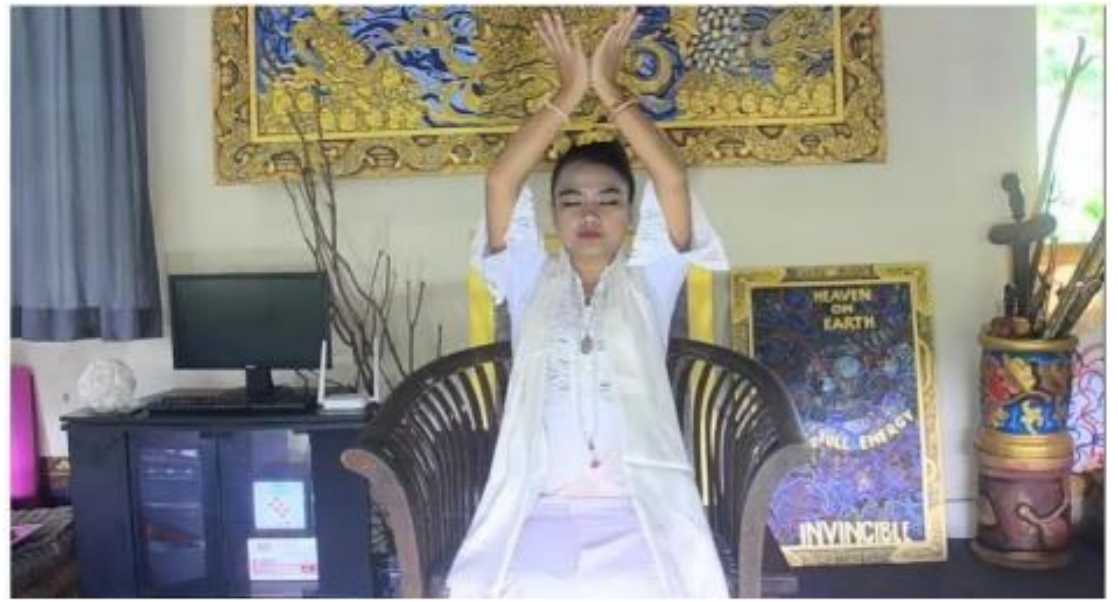

Dokumentasi: Mia,2020

\section{SIMPULAN}

Dari uraian pembahasan diatas, dapat diambil kesimpulan untuk memberikan berbagai penjelasan dan intisari singkat tentang hasil penelitian ini,antara lain:

1. Proses pelaksanaan ritual Parisudha vayu di Pasraman Kayu Manis Lata mahosadhi Desa Tegalmengkeb Kecamatan Selemadeg Timur Kabupaten Tabanan yaitu Tahap persiapan adalah tahap pertama pada suatu kegiatan keagamaan maupun lainnya. Tahap persiapan merupakan tahap dimana para pelaksana ritual dapat mempersiapkan berbagai sarana dan prasarana suatu ritual yang akan dilaksanakan. Selanjutnya Tahap pelaksanaan dimana peserta diminta untuk memohon izin kepada Hyang Leluhur untuk melaksanakan Parisudha vayu dan memohon agar selama prosesi ritual berlangsung dengan lancar dengan tahapan Karosodhana penyucian kedua tangan, Cakra bhuwana, merasakan keberadaan gelembung energi alam. Terakhir peserta telah melaksanakan aktivasi Parisudha vayu dan telah direstui oleh Dewa Vayu dan mendapatkan 3 pasword untuk rutin dilaksanakan sehari-hari. 2. Bentuk-bentuk komunikasi transendental dalam pelaksanaan ritual Parisudha vayu di Pasraman Kayu Manis Lata mahosadhi Desa Tegalmengkeb Kecamatan Selemadeg Timur Kabupaten Tabanan yaitu terlihat dari dua bentuk komunikasi. Pertama (1) Bentuk Komunikasi
Transendental dalam jenis komunikasi Verbal pada ritual Parisudha vayu yang berisikan wejangan Ida Mahaprabu Patni, sebelum, saat berlangsung dan setelah ritual ini dilaksanakan. Mulai dari Inisiator/ aktivator ritual mengetahui kesiapan dan kesungguhan hati umat setelah mendengarkan dharma wacana dari Aktivator. Selanjutnya doa mantra pembuka ritual Parisudha vayu dan ditutup dengan tahap akhir pemberian tiga password yang sudah diinisiasi yaitu, Jay Narayana, Jay Sri Hanoman, Jay Mahaprabhu. Kedua

2. Bentuk Komunikasi Transendental dalam jenis komunikasi Non Verbal pada ritual Parisudha vayu,berupa gerakan gerakan simbol yang relevan dengan keyakinan umat Hindu yang memiliki tujuan dan makna filosofis. Dengan Lima terminasi yaitu : Sarana Banten Pejati saat aktivasi ritual Parisudha vayu, Makna dan arti lambang Ritual Parisudha vayu, Pola Gerakan Pembersihan Tangan ( Karosodhana ), pola gerakan penyucian padma mudra (Cakra Bhuwana) dan pola komunikasi transendental (Parisudha vayu).

3. Implikasi komunikasi transendental terhadap aspek kehidupan masyarakat setelah melaksanakan ritual Parisudha vayu di Pasraman Kayu Manis Lata mahosadhi Desa Tegalmengkeb Kecamatan Selemadeg Timur Kabupaten Tabanan, diantaranya meliputi implikasi terhadap kehidupan religius umat pada aktivitas keagamaan umat dan 
hubungannya dengan masyarakat lintas agama. Selanjutnya implikasi terhadap kehidupan keluarga umat yang paling dekat pada implikasi kesehatan keluarga usai melaksanakan ritual parisudha vayu. Terakhir implikasi terhadap kehidupan sosial umat yang berpengaruh pada penggunaan sosial media oleh umat yang rutin melaksanakan ritual parisudha vayu.

\section{SARAN}

1. Kepada Tokoh Agama dalam halnya meningkatkan Sradha dan Bhakti umat Hindu serta menjalankan tujuan kita sebagai umat Hindu yaitu: "Mokhsartam Jagathita ya ca iti Dharma", maka sangat penting halnya para tokoh agama Hindu seperti Sulinggih, para Rsi dan Pemangku mengunggah lebih luas tentang ritual parisudha vayu yang dapat dilakukan oleh setiap kalangan dari Umat Hindu bahkan masyarakat lintas agama dan negara. Dengan demikian tidak ada yang menganggap bahwa ritual ini sebagai sebuah aliran baru melainkan sebuah intisari ajaran Weda dalam perspektif kitab Bhagawadgita.

2. Kepada masyarakat Hindu diharapkan bahwa di zaman Kali ini, terutama dalam menjalani era Globalisasi, umat Hindu masih banyak terikat keduniawian. Maka sangat diperlukan kesadaran spiritual mengingat pentingnya keyakinan dan kepercayaan kita kepada Ida Sang Hyang Widhi Wasa beserta manifestasinya. Dengan demikian diharapkan pada umat Hindu memahami dan tekun melakukan komunikasi transendental melalui ritual parisudha vayu karena dengan salah satu bentuk Samadhi ini salah satu jalan bagaimana menunjukkan cinta kasih mendalam kepada Tuhan.

3. Kepada Peneliti lain, dengan adanya penelitian ini, diharapkan dapat menjadi pedoman dan kajian pustaka dalam mengembangkan penelitian baru mengenai komunikasi transendental lebih baik lagi dan dapat menjadi acuan dalam pembelajaran terkait perkembangan metodologi penelitian yang mengacu pada konsep ajaran Hindu lebih dalam. Sehingga melalui penelitian lain dari komunikasi transendental dapat diketahui dan dirasakan bagaimana implikasinya, serta tidak dijadikan lahan bisnis demi kepentingan umat Hindu

\section{DAFTAR PUSTAKA}

Hardin, 2016. Komunikasi Transendental Dalam Ritual Kapontasu Pada Sistem Perladangan Masyarakat Etnik Muna, (Jurnal Penelitian Komunikasi dan Opini Publik Vol. 20) Fakultas Ilmu Budaya Universitas Halu Oleo (UHO) Kendari.

Liliweri, Alo, Dr, M.S, 2009. Makna Budaya dalam Komunikasi Antarbudaya. LKiS: Yogyakarta.

Littlejohn, Stephen W \& Karen A Foss, 2009. Teori Komunikasi. Edisi 9. Penerbit Salemba Humanika, Jakarta.

Mulyana, Deddy. 2007. Ilmu Komunikasi: Suatu Pengantar. Bandung : Remaja Rosdakarya.

Mulyana, Deddy. 2010. Ilmu Komunikasi Suatu Pengantar. Bandung : Rosdakarya

Nina, Winangsih Syam. 2015. Komunikasi Transendental Perspektif Sains Terpadu.Bandung: PT. Remaja Rosdakarya.

Pudja, G. MA. SH, 2005. Bhagawad Gita (Pancama Veda), Surabaya: Paramita.

Palapah, M.O. dan Atang Syamsudin.1983. Studi Ilmu Komunikasi. Bandung:UNPAD,

Rusdika, I Wayan dkk. 2018. Komunikasi Transendental Mapajejiwan dalam UpacaraMapaselang di Pura Penataran Agung Pucak Mangu Banjar Tinggan Desa Pelaga Kecamatan Petang Kabupate Badung (Jurnal Penelitian Agama Hindu). Denpasar: IHDN Denpasar 